\title{
A Collaborative Study of the Measurement of Glycosylated Haemoglobin by Several Methods in Seven Laboratories in the United Kingdom
}

\author{
B.J. Boucher, J. M. Burrin, B.J. Gould, P. N.John, G. Lewis, C. Owens, R. Paisey, C. A. Pennock, P. Y. W. Poon, \\ I.S. Ross, S. G. Welch, J. M. White \\ For authors' addresses see Table 1
}

\begin{abstract}
Summary. A collaborative study compared methods for measuring glycosylated haemoglobin in seven laboratories in the United Kingdom. No satisfactory standard for general use was found. Satisfactory internal quality control systems were in use for each assay which allowed the maintenance of a normal range in each participating laboratory. No satisfactory quality control system suitable for general use could be identified. Costs and convenience of the assays are reported. The technical problems with each type of assay and precautions for their use were identified, such as the need for standardization in incubation times, the practicability of automation of colorimetric assays, and the precision of $\mathrm{pH}$ needed for buf-
\end{abstract}

fers in column separation methods. The relevance of the technical problems to interpretation of measurements is also considered. It is concluded that laboratories measuring glycosylated haemoglobin should maintain a normal range, use inhouse' quality controls to monitor assay performance and keep clinical colleagues informed of the findings and of any changes in methodology that might affect the interpretation of results.

Key words: Diabetes mellitus, glycosylated haemoglobin, laboratory techniques, quality control systems, standards.
A collaborative study on the measurement of glycosylated haemoglobin was made by seven groups of workers. The study included measurement of glycosylated haemoglobin by small column separation, colorimetric analysis (with and without automation), iso-electric focussing and electroendosmosis. The study aimed to identify the advantages and disadvantages of many of the available methods for use in busy service laboratories. The problem of inclusion of short-term adducts in some of the measurements is considered. Because the demand for the estimation is growing [1], an attempt was made to identify standards for use in the assays and quality control systems that might assist in achieving conformity of results between different laboratories.

\section{Methods}

Table 1 shows the workers involved in each Laboratory. Table 2 shows the methods used. Laboratories 1-5 used a variety of ion-exchange column chromatographic separation methods (small or medium sized columns) dependent on the reduced charge on some forms of glycosylated haemoglobin $\left(\mathrm{HbA}_{1}\right)$ and based on the original method of Abraham et al. [2] and its modifications [3, 4]. These methods were used at room temperature and include the Schiff bases (i. e. temporary adducts) in the estimations. Colorimetric methods, based on that of Flückiger and Winterhalter [5], were used by Laboratories 2, 6 and $7[6,7]$. The colour developed by reaction of the hydroxymethylfurfural (5-HMF) (produced by boiling haemoglobin in dilute oxalic acid) with thio-barbituric acid is mainly due to the presence of $\mathrm{HbA}_{1 \mathrm{c}^{-}}$ Laboratories 2, 6 and 7 each compared the values for their fructose or 5-HMF standards with column separation values (either of bloods used as standards, or of an 'in-house' series of bloods) in order to express the measured 5-HMF as percentage total glycosylated haemoglobin (ketoamine form), having previously demonstrated significant correlation between the column separation $\mathrm{HbA}_{1}$ results and 5-HMF levels in an 'in-house' series of blood samples [7]. Laboratory 3 used electroendosmosis [8] on gel plates, in which the $\mathrm{HbA}_{1}$ moves through the charged hydroxyl groups present in the gel during electrophoresis. Laboratory 5 used iso-electric focussing with alignment of haemoglobins along a $\mathrm{pH}$ gradient in gel plates according to their individual iso-electric points $[9,10]$. Laboratory 4 also used the phytic acid method where non-glycosylated haemoglobin is measured as a proportion of total haemoglobin by being reacted with phytic acid and quantitated by the spectral shift produced [11] (Table 2).

\section{Collaborative Studies}

Study I. Each of the seven centres in turn circulated ten samples, of which five were from diabetic and five from non-diabetic subjects; the origin of the samples was known only to the senders. The samples were packed with ice in standard sealed containers and sent on the day of bleeding. Samples were received by each laboratory the following day and then stored at $4{ }^{\circ} \mathrm{C}$ before preparation for assay, 3 days after original sampling. 
Table 1. Laboratories and workers involved with collaborative study of glycosylated haemoglobin estimation

\begin{tabular}{|c|c|c|}
\hline No. & Laboratory & Collaborative workers \\
\hline 1 & $\begin{array}{l}\text { Department of Haematology, } \\
\text { Kings College Hospital, } \\
\text { London }\end{array}$ & $\begin{array}{l}\text { Professor J. M. White } \\
\text { Dr. P. N.John }\end{array}$ \\
\hline 2 & $\begin{array}{l}\text { Department of Medicine, } \\
\text { Southmead Hospital, and } \\
\text { Department of Paediatric } \\
\text { Chemical Pathology, } \\
\text { Bristol Maternity Hospital, } \\
\text { Bristol }\end{array}$ & $\begin{array}{l}\text { Dr. M. Hartog } \\
\text { Dr. R. Paisey } \\
\text { Dr. C.A. Pennock } \\
\text { Ms C. Owens }\end{array}$ \\
\hline \multirow[t]{2}{*}{3} & $\begin{array}{l}\text { Department of Biochemistry, } \\
\text { St. Lukes Hospital and } \\
\text { University of Surrey, }\end{array}$ & Dr. G. Lewis \\
\hline & Guildford & Dr. B.J.Gould \\
\hline 4 & $\begin{array}{l}\text { Departments of Biochemistry and } \\
\text { Metabolic and Endocrine Unit, } \\
\text { The London Hospital Medical College, } \\
\text { London }\end{array}$ & $\begin{array}{l}\text { Dr. S. G. Welch } \\
\text { Dr. B. J. Boucher }\end{array}$ \\
\hline 5 & $\begin{array}{l}\text { Diabetes Research Laboratory, } \\
\text { Radcliffe Infirmary, } \\
\text { Oxford }\end{array}$ & $\begin{array}{l}\text { Dr. R.C. Turner } \\
\text { Dr. P. Y. W. Poon } \\
\text { Mrs. C. Whittle }\end{array}$ \\
\hline 6 & $\begin{array}{l}\text { Department of Clinical Biochemistry } \\
\text { Royal Victoria Infirmary, } \\
\text { Newcastle Upon Tyne }\end{array}$ & $\begin{array}{l}\text { Professor } \\
\text { K.G.M. M. Alberti } \\
\text { Dr. J.M. Burrin } \\
\text { Dr. L. Ashworth }\end{array}$ \\
\hline 7 & $\begin{array}{l}\text { Department of Clinical Pathology, } \\
\text { University of Aberdeen, } \\
\text { Aberdeen }\end{array}$ & Dr. I. S. Ross \\
\hline
\end{tabular}

Study 2. A co-ordinator (non-bench-worker) sent four blood samples as 'unknowns' to each centre weekly for 4 weeks. Assays were carried out 3 days later. Two of the four samples each week were duplicate normal bloods and on 3 of the 4 weeks these came from the same subject. The other samples each week were duplicate diabetic samples. Sample preparation was as in Study 1.

Study 3. Each of the three laboratories using colorimetric methods, was sent a set of fructose standards (made up in isotonic saline) for assay by its own method.

Collation of Results. The results of each of the studies were returned each week to the co-ordinator for collation and analysis.

Statistical Analysis. Results are expressed as mean \pm SEM, Student's t-tests on the differences between the means, correlation coefficients, regressions of individual assay results upon the iso-electric focussing results and the within and between assay variance were calculated by standard methods [12].

Quality Control Data. A freeze dried haemoglobin $\mathrm{A}_{1}$ preparation, made available from the USA through the Radiochemical Centre, Amersham, UK as a possible quality control, was assayed both freshly re-constituted and after 1 and 2 weeks of storage at $-20^{\circ} \mathrm{C}$ in each of three centres (Laboratories 1,5 and 7).

Internal Quality Control Scheme in Use by Each Laboratory (Table 6). Internal quality control schemes were also identified in each individual laboratory at the beginning of the study, together with the coefficients of variation within and between assay for each method.
Laboratories 1-5, using column chromatographic methods and lysates of blood stored at $-20^{\circ} \mathrm{C}$, obtained consistent results over several weeks, with coefficients of variation of $3 \%-5 \%$ and $4 \%-8 \%$ within, and between, batches. Storage at $-70^{\circ} \mathrm{C}$ gave similarly consistent results over several months. In addition, repeated samples from healthy laboratory workers gave very consistent values with a coefficient of variation of $3 \%$ between assays. Routine assay runs were discarded if values fell outside this level of variation. Laboratory 2 reported the use of a fructose standard for their colorimetric method, to which their values for this method were corrected. Laboratory 6 used pooled haemolysates stored at $-70^{\circ} \mathrm{C}$ as internal quality controls. Laboratory 7 used bovine haemoglobin as an internal quality control (lysates stored at $-70^{\circ} \mathrm{C}$ gave levels within \pm one SD over 6 months and this was maintained in the present studies). Iso-electric focussing and electroendosmosis users (Laboratories 3 and 5) used 'in-house' quality controls similar to those of the laboratories using column separation techniques, with between assay variation within \pm one SD. The within-and-between-assay coefficients of variation obtained with these assays was $3 \%-5 \%$ and $4 \%-7 \%$, respectively. These methods were in use during the three studies, so that consistency of internal quality control was maintained.

\section{Results}

\section{Study I (Tables 3 and 4)}

The values for diabetic patients were significantly higher than for non-diabetic subjects for each method (Table 4). There was no overlap of normal and diabetic values by four of the five column separation methods or by iso-electric focussing. The large overlap in Laboratory 5 appeared to be due to sample confusion in one week of the study; results from this week were omitted from further analyses. Overlap was present for all of the colorimetric methods (in 2-7 of 35 diabetic samples per laboratory). Results for iso-electric focussing lay at about the middle of the overall ranges of values found for each set of weekly results on the diabetic samples by column and colorimetric methods. Figure 1 shows the similarities of the trends in measurement on one week's samples for all the methods used (full data available from the authors on request). The regression equations for each laboratory method against the values on isoelectric focussing are shown, together with their correlations, in Table 5. Table 3 shows that five and four of the seven methods gave their highest and lowest weekly means (for normal subjects) respectively, to coincide, demonstrating similarities of trends in measurement between methods and laboratories.

\section{Study 2}

The normal blood samples (three in duplicate on one subject) also gave consistent values by each method (Table 4). For column separation methods the mean was $7.59 \pm 1.55 \%$ (range: $6.08-9.1 \%$ ) and for colorimetric separation methods, $5.71 \pm 1.46 \%$ (range: $4.55 \%-7.05 \%)$. The means for iso-electric focussing and electroendosmosis were $6.81 \%$ and $6.8 \%$, respectively; thus again lying between the means of the values found by column and colorimetric methods. The values for the 
Table 2. Glycosylated haemoglobin measurements: methods used and references

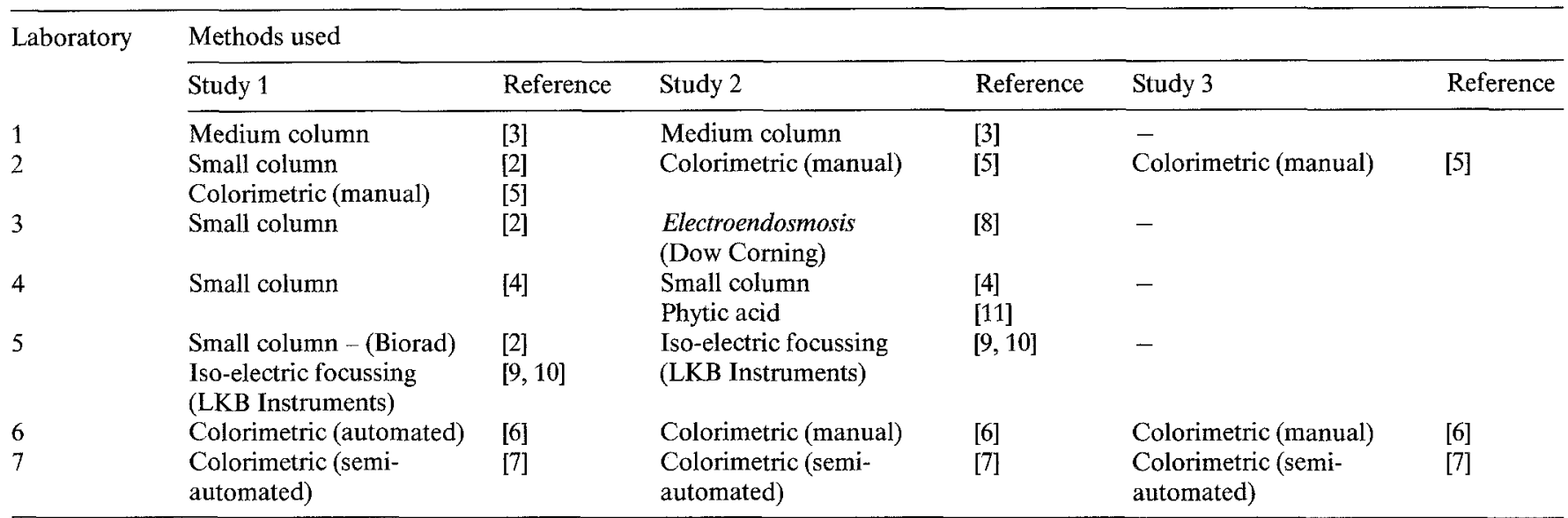

Table 3. Study 1: Weekly mean values of $\mathrm{HbA}_{1}$ for five normal subjects by each laboratory method

\begin{tabular}{|c|c|c|c|c|c|c|c|c|}
\hline Laboratory & Method used & \multicolumn{7}{|c|}{ Weeks } \\
\hline 1 & Column separation & 7.88 & $8.84^{\mathrm{a}}$ & 7.7 & 8.14 & 8.14 & 7.76 & $6.70^{\mathrm{b}}$ \\
\hline 3 & Column separation & $6.58^{\mathrm{b}}$ & - & 7.24 & $8.02^{\mathrm{a}}$ & 7.94 & 7.65 & 7.74 \\
\hline 4 & Column separation & 8.02 & 7.50 & $7.14^{b}$ & 7.76 & $8.5^{\mathrm{a}}$ & 7.8 & 7.38 \\
\hline 5 & Column separation & $4.5^{b}$ & - & $10.16^{\mathrm{a}, \mathrm{c}}$ & 5.54 & 7.08 & 5.84 & 5.64 \\
\hline 6 & Colorimetric & 6.42 & 6.78 & 6.28 & $7.22^{\mathrm{a}}$ & 6.85 & 7.65 & $5.94^{b}$ \\
\hline 7 & Colorimetric & 5.22 & 4.4 & 5.8 & 5.54 & 5.1 & $6.73^{\mathrm{a}}$ & $4.08^{b}$ \\
\hline
\end{tabular}

${ }^{a}=$ highest weekly mean; ${ }^{b}=$ lowest weekly mean; ${ }^{c}=$ samples confused - omitted from further analysis (week 3 only); $-=$ samples lost in transit

Table 4. Study 1: Glycosylated haemoglobin levels in diabetic and non-diabetic subjects

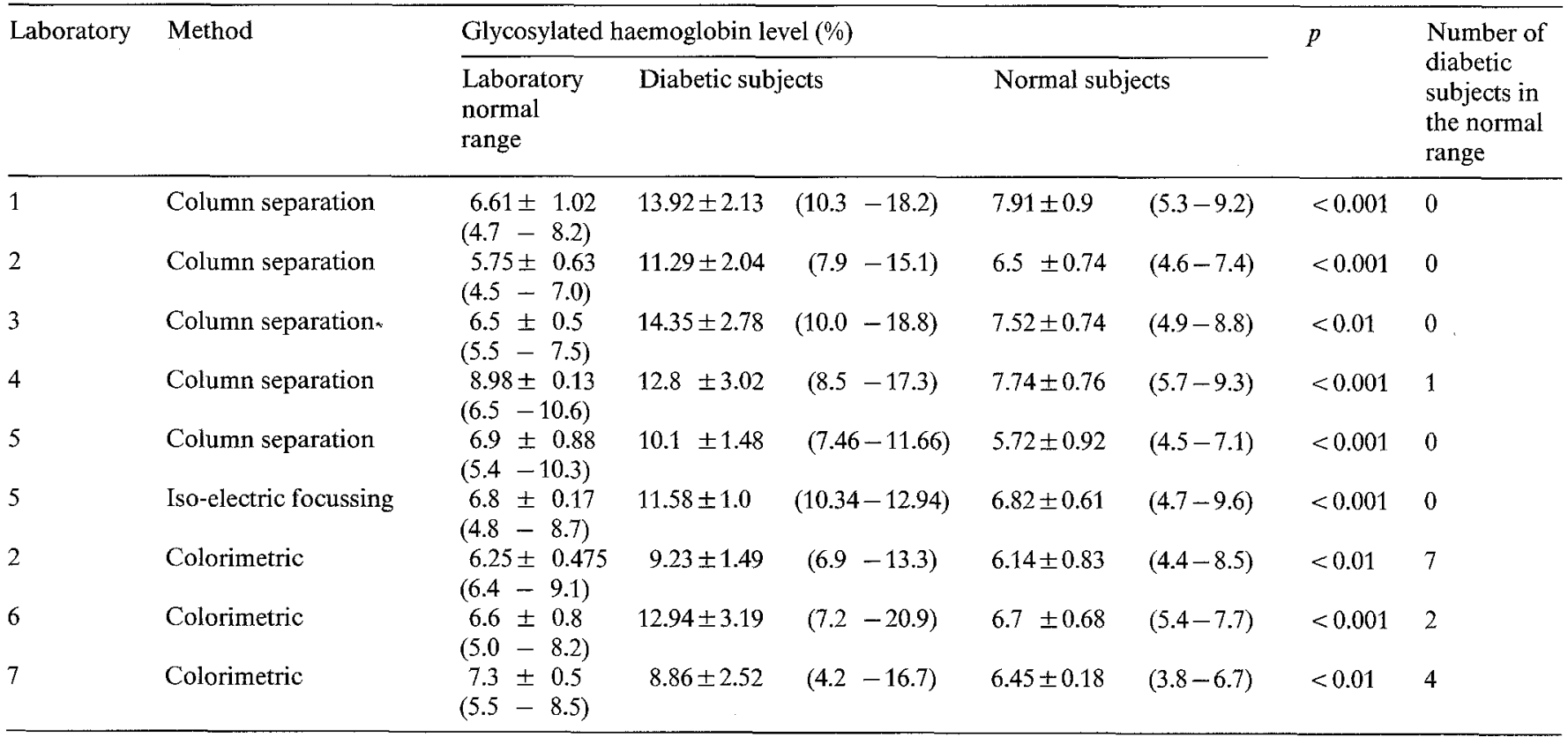

Results expressed as mean $\pm \mathrm{SD}$; range in parentheses 
Table 5. Study 1: Glycosylated haemoglobin estimations and regression equations for individual laboratory estimations upon iso-electric focussing values

\begin{tabular}{lllll}
\hline Laboratory & Method & Regression equation & Coefficient of correlation $(r)$ & $\begin{array}{c}\text { Significance of } r \\
p\end{array}$ \\
\cline { 3 - 5 } & & Intercept slope & & $<.88$ \\
\hline 2 & Column separation & $\mathrm{Y}=2.07535+0.614 \mathrm{x}$ & 0.99 & $<0.001$ \\
4 & Column separation & $\mathrm{Y}=0.720+1.063 \mathrm{x}$ & 0.94 & $<0.001$ \\
1 & Column separation & $\mathrm{Y}=2.642+0.912 \mathrm{x}$ & 0.83 & $<0.001$ \\
2 & Colorimetric & $\mathrm{Y}=3.588+0.262 \mathrm{x}$ & 0.96 & $<0.001$ \\
7 & Colorimetric & $\mathrm{Y}=0.3306+0.658 \mathrm{x}$ & 0.95 & $<0.001$ \\
6 & Colorimetric & $\mathrm{Y}=-2.41+0.32 \mathrm{x}$ & & $<0.001$ \\
3 & Electroendosmosis & $\mathrm{Y}=-0.531+1.08 \mathrm{x}$ & & \\
\hline
\end{tabular}
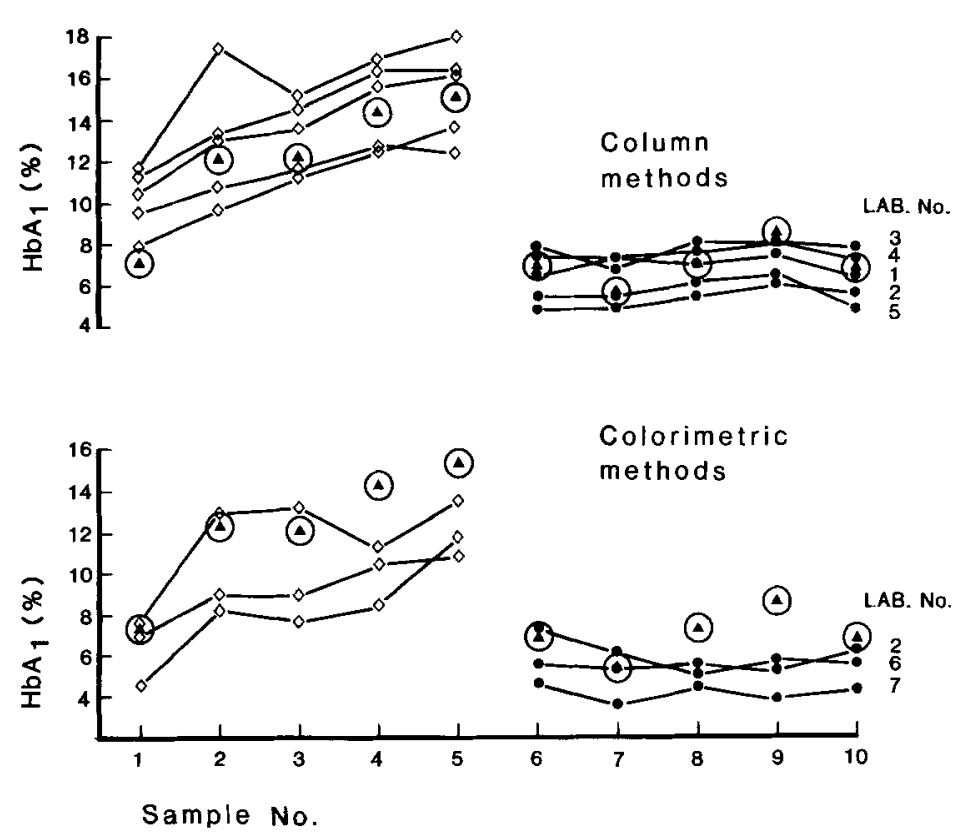

Fig. 1. Glycosylated haemoglobin levels of five normal $(-\infty)$ and five diabetic $(\diamond \longrightarrow)$ samples by each method. Iso-electric focussing results (2) for week 6 of Study 1

three diabetic samples each assayed in duplicate were similarly related to assay method but were too few for detailed analysis.

\section{Study 3}

The assay values for the unknown fructose standards are shown in Figure 2 where it can be seen that the results in each laboratory were closely correlated with the fructose levels. Laboratories 6 and 7, having been corrected to column separation $\mathrm{HbA}_{1}$ values obtained on previous runs (see Methods) gave higher values than those for Laboratory 2.

\section{Technical Considerations}

Differences in the ease of maintaining a routine service with the several techniques were apparent. Table 6

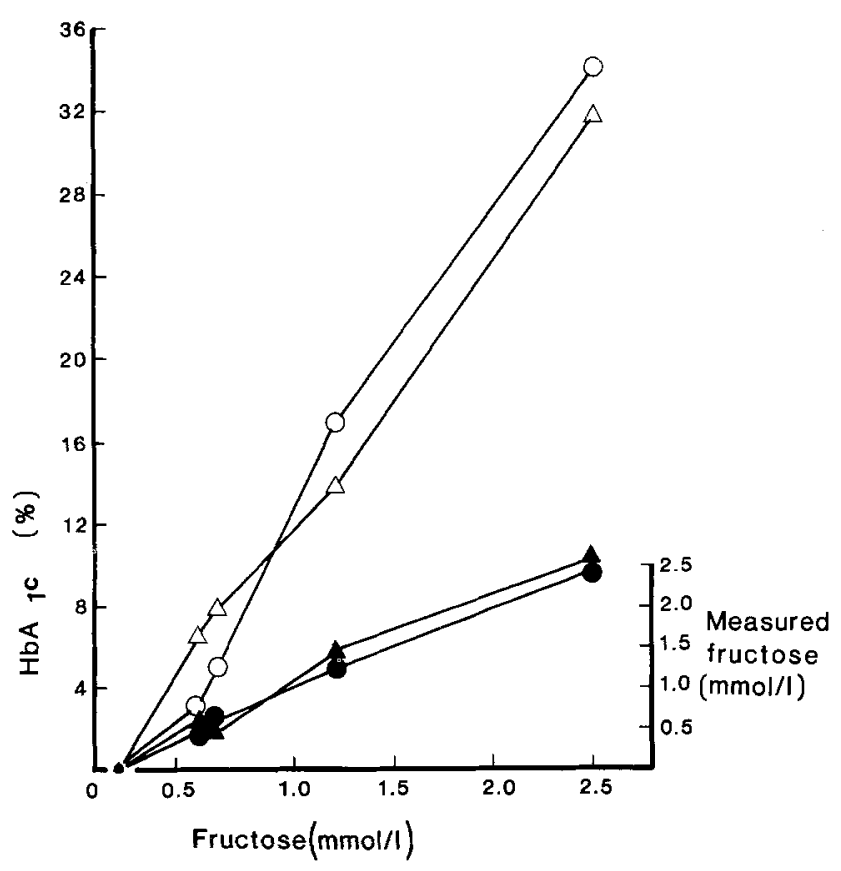

Fig. 2. Measurements made on fructose standard in Study 3. Laboratory 2: $\mathrm{HbA}_{\mathrm{ic}}$ levels $\longrightarrow$, fructose estimation - Laboratory 6: $\mathrm{HbA}_{1 \mathrm{c}} \mathrm{O} \longrightarrow$. Laboratory 7: $\mathrm{HbA}_{1 \mathrm{c}} \triangle \longrightarrow \Delta$

shows the group's considered views on the comparative costs, labour required, sensitivity to the environment [16] and robustness of each assay system. The inclusion of short lived $\mathrm{HbA}_{1}$ in the column and electroendosmosis and phytic acid methods should be noted.

\section{External Quality Controls}

The trial standard material $\left(\mathrm{HbA}_{1}\right)$ circulated and assayed by three of the laboratories $(2,4$ and 6$)$ gave considerable variation in results by column assays irrespective of whether samples were kept 1-2 weeks after opening, or whether fresh vials were opened and assayed 7 and 14 days later (e.g. initial values of $12.0 \%$ and $7.7 \%$ rose to $17.8 \%$ and $11.9 \%$ respectively or fell from $10.7 \%$ to $6.2 \%$ and $7.5 \%$ ). On colorimetric assay the values were lower but equally variable. The results were closest to the four stated values of $7.5 \%-15.2 \%$ when as- 


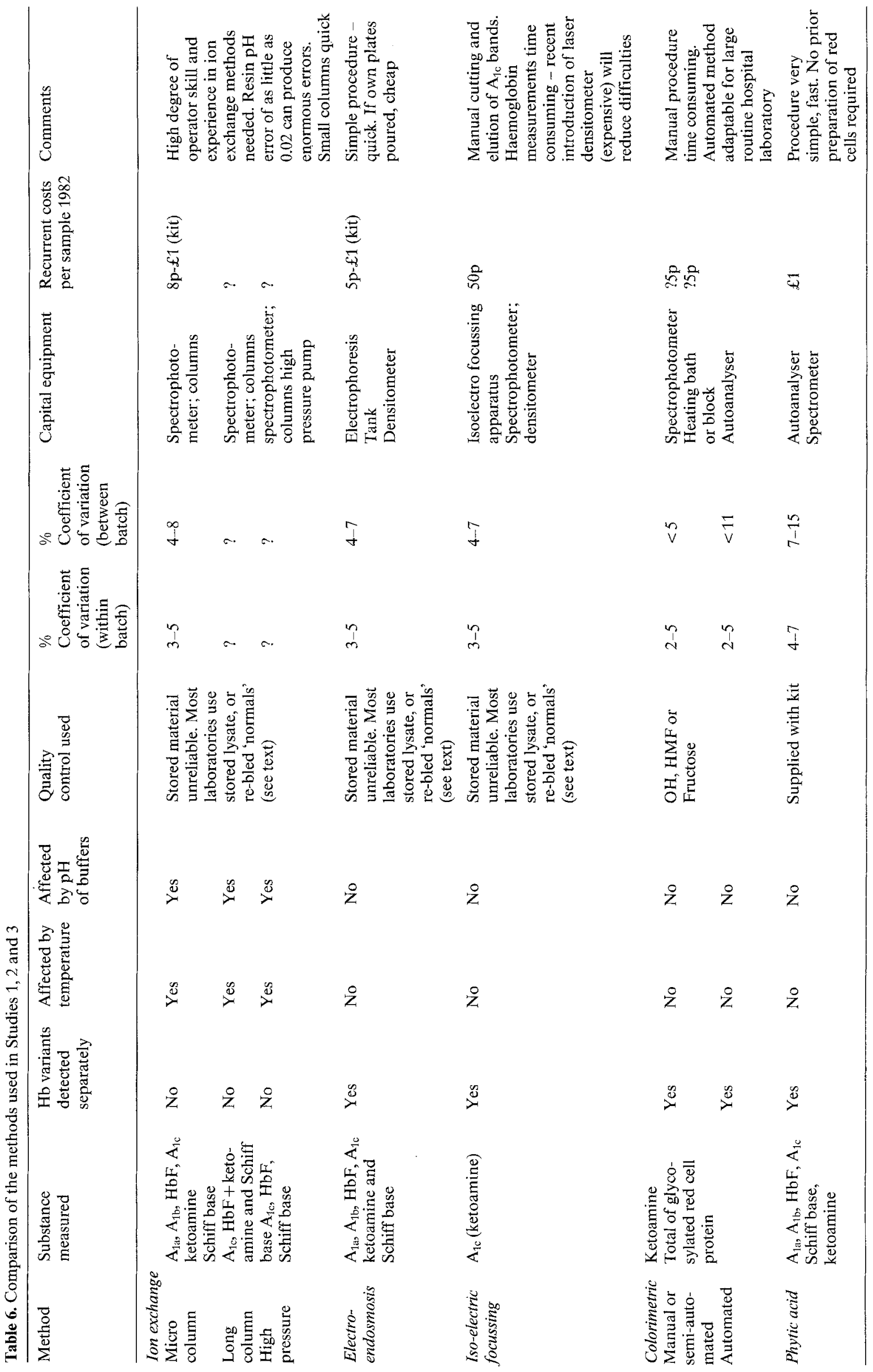


sayed fresh the first week by column methods. Similar work on purified $\mathrm{HbA}_{1 \mathrm{c}}$ has shown rapid breakdown of the freeze-dried preparation with short-term storage (Welch S.G., unpublished data)

\section{Discussion}

Column separation methods give higher results than colorimetric methods as expected from previous reports [13]. This increase is partly due to the presence of shortlived adducts of $\mathrm{HbA}_{1 \mathrm{c}}$ (i.e. Schiff bases) which break down after some hours if glucose levels fall greatly, as for example after dialysis [14]. None of these studies (1979-1981) was carried out using such dialyses, but storage at room temperature overnight followed by 2 days at $4{ }^{\circ} \mathrm{C}$ would be expected to lower the glucose content of the samples significantly. The lack of overlap in small and medium column methods between diabetic and normal levels might be due to incomplete clearance of Schiff bases in the diabetic samples [15]. Since the colorimetric methods measure all forms of glycosylated haemoglobin other than short lived Schiff base adducts, they should be more sensitive discriminants for diabetic control than the column methods. The large number of diabetic samples giving values within the normal range by the colorimetric method was therefore an unexpected finding. The samples from diabetic patients giving colorimetric values in the normal range but raised values on column separation indicate either adequate control in the long-term but the presence of short-term hyperglycaemia (i.e. pre- $\mathrm{HbA}_{1 \mathrm{c}}$ etc. is present in significant amounts) or alternatively, denote inadequate control which would be missed on colorimetric assays. Despite reasonable time for decay of Schiff bases in these studies $[13,15]$, the samples were not dialysed so that the former explanation would be the more likely provided that the colorimetric methods were assumed to have been standardized correctly. No method with or without dialysis would have given appropriate results in any patient with haemolysis.

No useful inter-laboratory standards were clearly identified for any of the assay systems used. All the internal quality control systems used for the several assay methods as reported above were adequate for checking on the maintenance of 'in-house' normal ranges with within and between assay coefficients of variation of $3 \%-7 \%$ to $4 \%-11 \%$, respectively, though such ranges were of course different for different methods. (The phytic acid method at the time of the study gave a coefficient of variation up to $15 \%$ between assays and was not considered acceptable for use in the study).

Correction of results to one method chosen as a reference standard could be made, as shown by the significant regression of each set of results on the iso-electric focussing data, chosen because it lay in the middle of the ranges obtained and because the method appeared to be the least vulnerable to upset by changes in labora- tory temperature and conditions and because it should not measure short-lived adducts. This is however of no special additional benefit and would be a very difficult system to run nationally. Such correction might even cloud clinical judgement if the inclusion or non-inclusion of short-lived adducts were to be forgotten or ignored, or attempts to remove them to be incomplete. The correlation of results on iso-electric focussing with colorimetric methods was not significantly better than that with column separation methods, suggesting that short-lived adducts were not a sizeable problem in the interpretation of column methods, when samples had been stood 3 days before the assay.

Despite the problems of methodology and of interpretation, the serial quantitation of overall control is so obviously desirable [17-19] that this group feels that laboratories and clinics should persist in efforts to achieve an 'in-house' assay of $\mathrm{HbA}_{1}$.

No one method can yet be selected as the most costeffective.

The trend towards dialysis of samples before the assay should bring results by different methods closer together by reversing any short-lived $\mathrm{HbA}_{1}$, though it appears not to be necessary in colorimetric methods as used in these studies where glucose concentrations do not appear to affect the measurements [20]. Further studies on this aspect are still needed. Meanwhile, laboratories should measure and update their own normal ranges, use 'in-house' quality control to monitor batch assays, and keep their clinical colleagues informed of these values and of how any changes in methodology might affect the interpretation of results.

Acknowledgements. We thank Corning, Halstead, UK for the loan of the electrophoretic apparatus and the gift of materials, and the British Diabetic Association for the provision of facilities for meetings of the group and for payment of travel expenses to those attending progress meetings during the study. We also thank Amersham International for the supply of material.

\section{References}

1. Editorial (1977) Glycosylated haemoglobins and disease. Lancet 2: $22-23$

2. Abraham EC, Huff TA, Cope ND, Wilson JB, Bransome ED, Huisan THJ (1978) Determination of the glycosylated hemoglobins $\left(\mathrm{HbA}_{1}\right)$ with a new micro column procedure. Diabetes 27 : 931-937

3. Kynoch PAM, Lehmann H (1977) Rapid estimation (2⿺辶 hrs) of glycosylated haemoglobin for routine purposes. Lancet 2: 16

4. Welch SG, Boucher BJ (1978) A rapid micro-scale method for the measurement of haemoglobin $A_{1(a+b+c)}$ Diabetologia 14: 209-211

5. Flückiger R, Winterhalter KM (1976) In vitro synthesis of haemoglobin $A_{10}$. FEBS Letters 71 : 356-360

6. Burrin JM, Worth R, Ashworth LA, Currie S, Alberti KGMM (1980) Automated colorimetric estimation of glycosylated haemoglobins. Clin Chem Acta 106: 45-50

7. Ross IS, Gibson PF (1979) A semi automated method for the determination of glycosylated haemoglobin. Clin Chem Acta 98: $53-69$

8. Menard L, Dempsey ME, Blankstein LA, Aleyassine H, Wacks M, Soeldner JS (1980) Quantitative determination of glycosylated 
haemoglobin $A_{1}$ by agar gel electrophoresis. Clin Chem 26: 1598-1602

9. Jeppsson JO, Franzen B, Nilsson KO (1978) Determination of glycosylated haemoglobin fraction $\left(\mathrm{HbA}_{1}\right)$ in diabetes mellitus by thin layer electrofocussing. Science Tools 25: 69-72

10. Poon PYW, Whittle C (1980) Measurement of glycosylated haemoglobin using iso-electric focussing technique. Diabetologia 19: 563 (Abstract)

11. Moore EG, Stroupe SD, Blecka LJ (1980) Automated spectrophotometric assay for glycosylated hemoglobin. Diabetes 29 (Suppl 2): 70A

12. Snedecor GW, Cochran WG (1967) Statistical methods. Iowa State University Press, Iowa, USA

13. Bunn HF (1981) Evaluation of glycosyated haemoglobin in diabetic patients. Diabetes 20: 613-617

14. Svendsen PA, Christiansen JS, Soegard U, Welinder BS, Nerup J (1980) Rapid changes in chromatographically determined haemoglobin $A_{1 c}$ induced by short-term changes in glucose concentration. Diabetologia 19:130-136

15. Svendsen PA, Welinder BS, Nerup J (1980) The significance of rapid changes in $\mathrm{HbA}_{1 \mathrm{c}}$. Diabetologia 19: 318-319
16. Simon M, Essler J (1980) Critical factors in the chromatographic measurement of $\mathrm{HbA}_{1}$. Diabetes 29: 467-473

17. Gabbay KH (1976) Glycosylated hemoglobin and diabetic control. New Engl J Med 295: 443-444

18. Peterson CM, Jones RL (1977) Minor haemoglobins, diabetic 'control' and diseases of post-synthetic protein modification. Ann Int Med 87: 489-490

19. Editorial (1980) Haemoglobin $A_{1}$ and diabetes; a reappraisal. $\mathrm{Br}$ Med J 281: 1304-1305

20. Ploybutr S, Burrin JM, Alberti KGMM (1982) Rapid glycosylation of haemoglobin in vitro. A hazard of column chromatographic but not colorimetric techniques. Clin Chem: Letter 28 (5): $1233-4$

Received: 22 April 1982

and in revised form: 7 December 1982

Dr. B. J. Boucher

The Metabolic and Endocrine Unit

The London Hospital Medical College

Whitechapel

London E1 1BB, UK 